\title{
Re-emergence of tularemia in Germany: Presence of Francisella tularensis in different rodent species in endemic areas Philipp Kaysser*1, Erik Seibold ${ }^{1}$, Kerstin Mätz-Rensing², Martin Pfeffer ${ }^{1}$, Sandra Essbauer ${ }^{1}$ and Wolf D Splettstoesser ${ }^{1,3}$
}

\author{
Address: ${ }^{1}$ Bundeswehr Institute of Microbiology, Neuherbergstrasse 11, D-80937 Munich, Germany, ${ }^{2}$ German Primate Center, Kellnerweg 4, D- \\ 37077 Göttingen, Germany and 3Institute of Medical Microbiology, Virology and Hygiene, University Hospital Rostock, Schillingallee 70, D- \\ 18057 Rostock, Germany \\ Email: Philipp Kaysser* - philippkaysser@bundeswehr.org; Erik Seibold - erikseibold@ bundeswehr.org; Kerstin Mätz- \\ Rensing - kmaetz@gwdg.de; Martin Pfeffer - martin1pfeffer@bundeswehr.org; Sandra Essbauer - sandraessbauer@bundeswehr.org; \\ Wolf D Splettstoesser - wolfsplettstoesser@bundeswehr.org \\ * Corresponding author
}

Published: 17 November 2008

BMC Infectious Diseases 2008, 8:157 doi:10.1186/1471-2334-8-157
Received: 16 July 2008

Accepted: 17 November 2008

This article is available from: http://www.biomedcentral.com/I47I-2334/8/157

(c) 2008 Kaysser et al; licensee BioMed Central Ltd.

This is an Open Access article distributed under the terms of the Creative Commons Attribution License (http://creativecommons.org/licenses/by/2.0), which permits unrestricted use, distribution, and reproduction in any medium, provided the original work is properly cited.

\begin{abstract}
Background: Tularemia re-emerged in Germany starting in 2004 (with 39 human cases from 2004 to 2007) after over 40 years of only sporadic human infections. The reasons for this rise in case numbers are unknown as is the possible reservoir of the etiologic agent Francisella $(F$.) tularensis. No systematic study on the reservoir situation of $F$. tularensis has been published for Germany so far.

Methods: We investigated three areas six to ten months after the initial tularemia outbreaks for the presence of $F$. tularensis among small mammals, ticks/fleas and water. The investigations consisted of animal live-trapping, serologic testing, screening by real-time-PCR and cultivation.

Results: A total of 386 small mammals were trapped. F. tularensis was detected in five different rodent species with carrier rates of 2.04, 6.94 and $10.87 \%$ per trapping area. None of the ticks or fleas $(n=432)$ tested positive for $F$. tularensis. We were able to demonstrate $F$. tularensis-specific DNA in one of 28 water samples taken in one of the outbreak areas.

Conclusion: The findings of our study stress the need for long-term surveillance of natural foci in order to get a better understanding of the reasons for the temporal and spatial patterns of tularemia in Germany.
\end{abstract}

\section{Background}

Tularemia is caused by the gram-negative rod Francisella (F.) tularensis which is confined to the Northern Hemisphere, where small mammals such as rabbits, hares and voles are known to be involved in enzootic transmission cycles [1]. F. tularensis is regarded as a category A biological agent according to the classification of the CDC (Cent- ers for Disease Control and Prevention, Atlanta, GA, USA).

The last major outbreaks among humans in Germany took place in the late 1950s [2]. Since then a sharp decline in cases of tularemia was seen with less than five per year between 1960 and 2004 [3]. Likewise only four cases of 
tularemia among hares and rabbits were reported to the German authorities between 1983 and 1992 followed by a period without reports until 2004 [4] when tularemia was the cause of an outbreak among primates in ethological research facilities in Sennickerode (SEN) [3] and in 2005 in Göttingen (GÖ) [5]. Most strikingly, tularemia had never been described in both areas before. In November 2005 finally, the largest outbreak of human tularemia in Germany for 40 years has occurred in a group of hare hunters near the city of Darmstadt (DA) where 11 people got infected including one fatality [6]. Altogether a total of 39 human cases occurred in Germany from 2004 to 2007 [7]. All three areas were investigated in our pilot study in order to detect possible animal reservoirs of $F$. tularensis.

\section{Methods}

Live-trapping of small mammals was performed in all three distinct endemic areas (Figure 1) in June 2005 (SEN, area of approximately 50,000 $\mathrm{m}^{2}$ ), in September 2006 (GÖ, approx. 30,000 $\mathrm{m}^{2}$ ) and in October 2006 (DA, approx. $1.2 \mathrm{~km}^{2}$ ) - each within a time period of six to ten months after the initial outbreaks. The endemic areas were divided into up to five trapping areas - depending on size of the area and differences in vegetation (Figure 2).

Small mammals were decoyed and live-trapped with Sherman traps [8], ectoparasites were combed off and - where possible - blood samples were collected by heart-puncture under anaesthesia. After necropsy the species was mainly determined by phenotypic differentiation, in some cases by a PCR targeting the partial mitochondrial cytochrome $B$ gene as described before [8]. Tissue samples of approximately $0.5 \mathrm{~g}$ of liver and spleen were homogenized with $0.9 \mathrm{ml}$ of phosphate-buffered saline (PBS) using the FastPrep ${ }^{\mathrm{Tm}}$-system (QBiogene, Heidelberg, Germany). An aliquot of $20 \mu \mathrm{l}$ was then lysed with $180 \mu \mathrm{l}$ of lysis buffer containing proteinase $\mathrm{K}$ as previously described [3] and $5 \mu$ l were tested in duplicate using a realtime-PCR for the presence of the 16S rRNA-gene of F. tularensis (LightMix - -Kit Francisella tularensis, TIB MOLBIOL, Berlin, Germany). Positive samples were confirmed using a specific fopA-real-time-PCR (modified according to [9]). Conventional PCRs targeting a 30 bp-deletion in the FtM19 locus [10] and the region of differentiation 1 (RD1, [11]) followed to determine subspecies identity. Cultivation and isolation of the agent was attempted only with liver and spleen homogenates previously tested positive for F. tularensis by PCR $(10 \mu \mathrm{l}$ in dilution streak technique on Heart-Cysteine-, Columbia- and Thayer-Martin-agars and $50 \mu \mathrm{l}$ spread evenly on Heart-Cysteine-agar). Confirmation after growth on agar was done using the above chain of PCR-based methods combined with typical biochemical and morphologic features. Retain samples of all liver and spleen homogenates were stored for possible future use.
Serum samples were examined using an ELISA based on $F$. tularensis LPS as previously described [12]. A highly specific western blot was used as a confirmatory assay [12].

Ticks and fleas $(n=432)$ were pooled to a maximum of 20 per pool, homogenized and analysed by PCR as described above. Tick species were not determined due to the pilot study character of the investigations. The collection of ticks and fleas was done from the animal itself and by flagging in the small mammal trapping areas defined for every endemic area (Figure 2).

For water samples (collected throughout the entire DA endemic area, Figure 2), $1 \mathrm{ml}$ of each sample was sterilefiltered ( $1 \mu \mathrm{m}$ filter) to eliminate suspended matter, centrifuged with 20,000 g for 10 minutes and re-suspended in $50 \mu \mathrm{l}$ of PBS, $20 \mu \mathrm{l}$ were then lysed and tested by PCR as described above.

\section{Results}

A total of 386 small mammals were captured during the study, the overall carrier rate with $F$. tularensis as determined by the detection of specific DNA was $4.92 \%$ ( $\mathrm{n}=$ $386,95 \%$ confidence interval: $2.76-7.08 \%$, range: 2.04 - $10.87 \%$ ) in the three endemic areas (Table 1). The infected species were bank voles (Myodes glareolus; $4.49 \%$ ), water voles (Arvicola terrestris; $15.0 \%$ ), field voles (Microtus agrestis; $10.0 \%$ ), common voles (Microtus arvalis; $8.0 \%$ ) and yellow-necked fieldmice (Apodemus flavicollis; $2.9 \%)$. We found a significant difference in the infection rate among the three investigation sites DA, GÖ and SEN $\left(\mathrm{X}^{2}=7.34\right.$, degrees of freedom $\left.=2, \mathrm{p}=0.025\right)$, but not among the five positive rodent species $\left(\mathrm{X}^{2}=6.91\right.$, degrees of freedom $=4, \mathrm{p}=0.141$ ).

In none of the 432 ectoparasites from all three study sites F. tularensis-specific DNA could be detected.

Strains of $F$. tularensis were isolated from two water voles from the SEN area. Cultural identification, antibiotic resistance typing and PCR results showed that both strains belonged to subspecies $F$. tularensis holarctica, biovar I. None of 186 small mammals (including sera from 15 of the 19 infected mice, no insectivores) from which serum was available showed specific antibodies against $F$. tularensis.

Of the 28 water samples collected in the DA investigation, one sample tested positive for DNA of $F$. tularensis (Figure 2 , large red dot). This sample was taken on a spot with floating water of a small river, about $300 \mathrm{~m}$ from the next rodent capture site.

The habitats in which the outbreaks occurred consist mainly of alluvial, forest-like field biotopes surrounded 


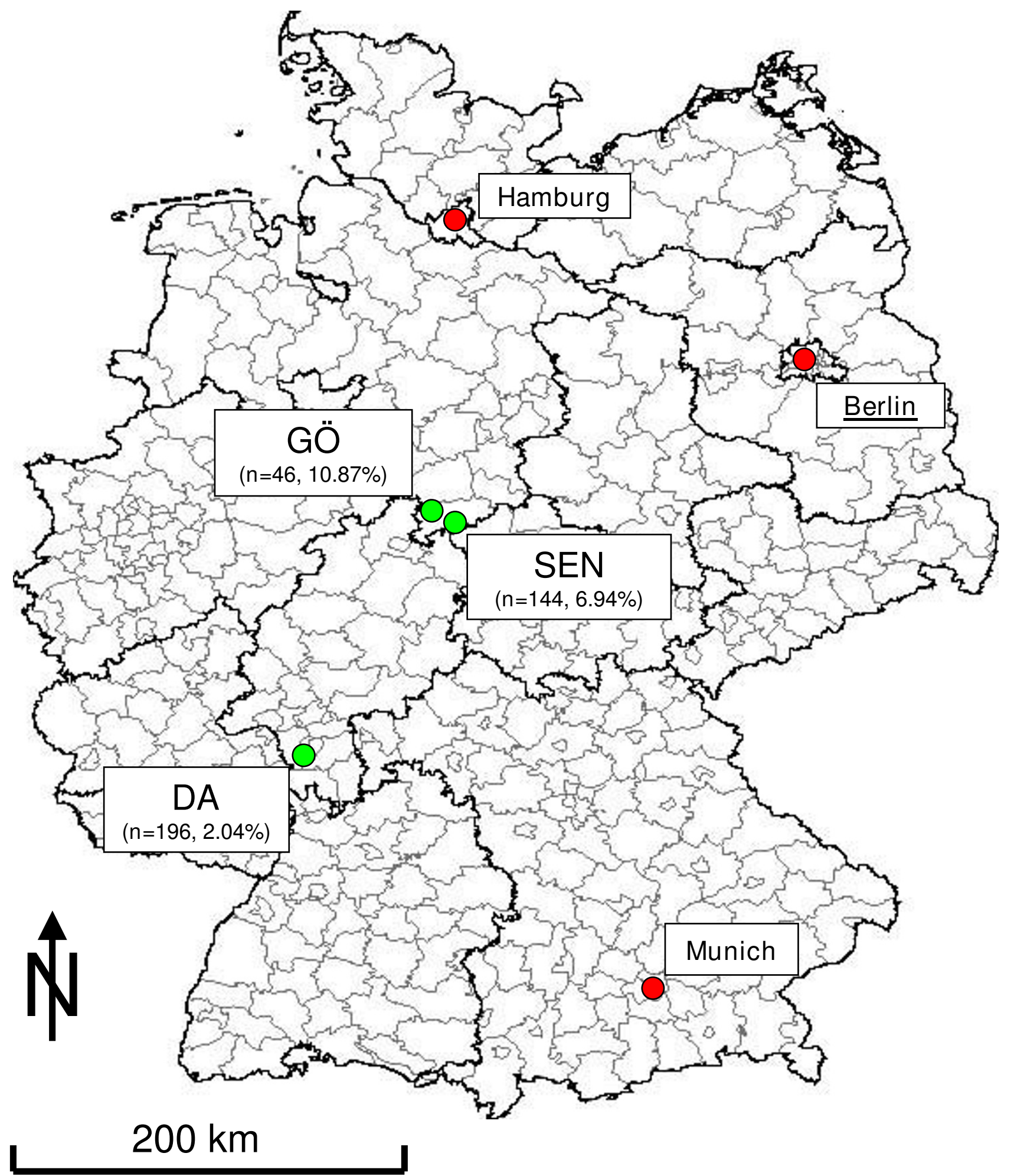

Figure I

Study sites, Germany, 2004-2006. Green dots indicate the investigation areas, red dots the three largest German cities for orientation. The number of small mammals caught and the $F$. tularensis detection rate are shown in parenthesis. 


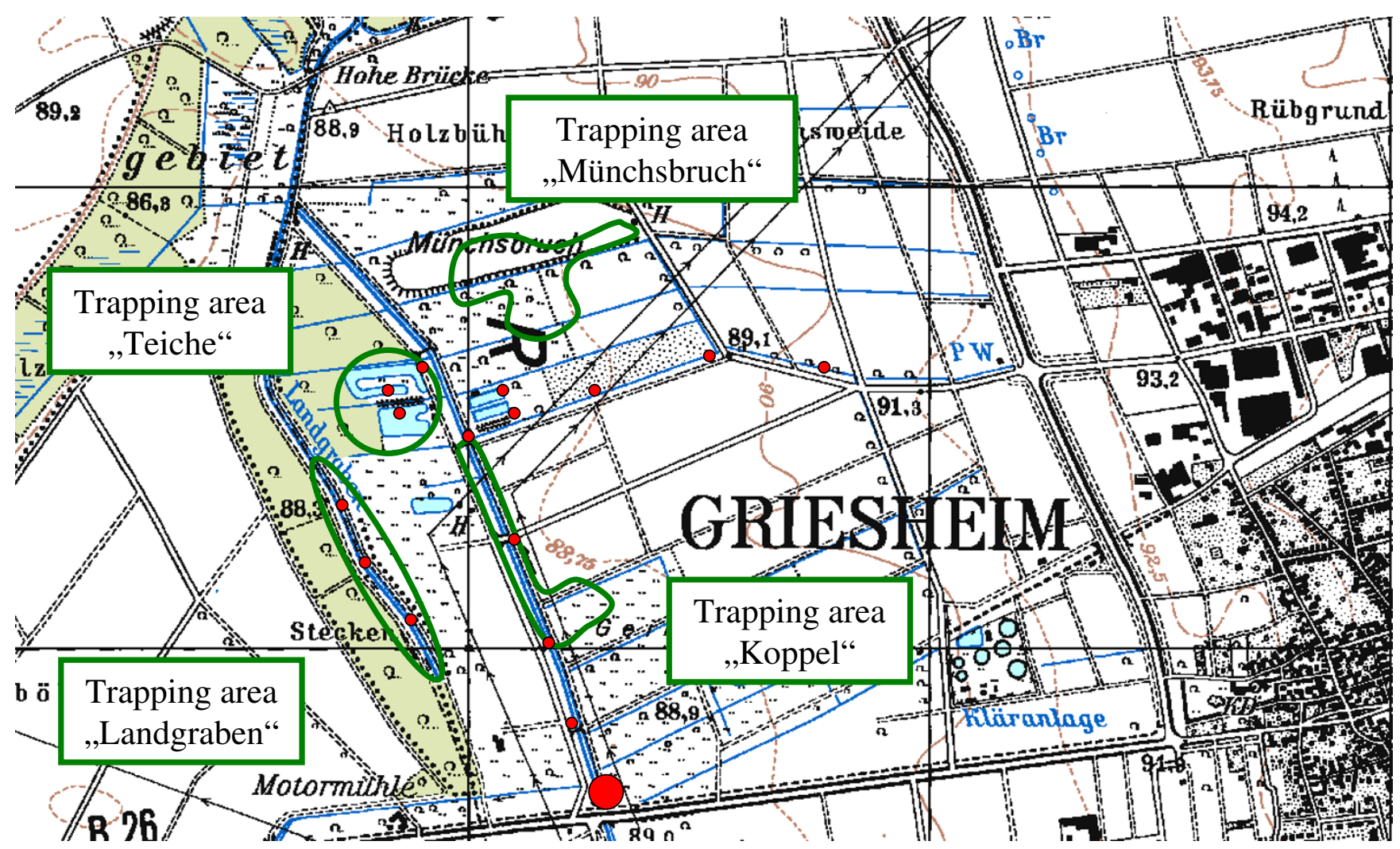

Figure 2

Distribution of rodent trapping areas (marked in green) and water sample collection sites (red dots) in an exemplary area (DA). The large red dot indicates the water sample tested positive for $F$. tularensis.

by areas of intensive agriculture in Göttingen (GÖ) and Sennickerode (SEN) and also sinuosities of the river Neckar near Darmstadt (DA). Habitat as well as geographic and climatic parameters were very similar to areas in the Czech Republic which seem to favour long-term persistence of $F$. tularensis [3]. In the region of Griesheim (DA investigation, years 1991-2007) the elevation above sea level was $90 \mathrm{~m}$, the mean annual air temperature was $10.9^{\circ} \mathrm{C}$ and the mean annual precipitation $610 \mathrm{~mm}$ (for data on GÖ and SEN see [3]). Except for the mean annual sunshine duration - which is usually lower throughout entire Germany - these characteristics are in accordance with the model suggested in [13].

\section{Discussion}

Human tularemia gained importance in Germany in the years after World War II [2], a total of about 715 cases were notified from 1949-2008 [14]. No systematic investigation on possible reservoirs of tularemia in endemic areas has been published for Germany so far. Public interest in tularemia increased in the last four years due to small localized outbreaks in the areas investigated in this study. Data on the prevalence of $F$. tularensis in rodents as the suspected natural reservoir is of significant importance to German public health authorities in the endemic areas to provide a risk assessment for persons inhabiting or working in these areas.

Our study demonstrates that natural foci do exist in Germany with incidences of $F$. tularensis in rodents of up to $10 \%$ in certain foci. The fact that no specific antibodies to $F$. tularensis were found in any of the infected or uninfected animals argues in favour for the traditional view that F. tularensis seems to be mainly fatal for infected 
Table I: Detection of $F$. tularensis in different small mammal species

\begin{tabular}{lcccc}
\hline & \multicolumn{3}{c}{ No. Positive/No. Detected (\%) } \\
\cline { 2 - 5 } Small mammal species & Darmstadt (DA) & Göttingen (GÖ) & Sennickerode (SEN) & Total (DA, GÖ, SEN) \\
\hline Apodemus agrarius & $-/-*$ & $0 / 3$ & $-/-$ & $0 / 3$ \\
Apodemus flavicollis & $1 / 30(3.33)$ & $0 / I I$ & $1 / 28(3.57)$ & $2 / 69(2.90)$ \\
Apodemus sylvaticus & $0 / 52$ & $-/-$ & $-/-$ & $0 / 52$ \\
Arvicola terrestris & $0 / 3$ & $-/-$ & $6 / 37(16.22)$ & $6 / 40(15.00)$ \\
Microtus agrestis & $0 / 1$ & $1 / 8(I 2.5)$ & $0 / 1$ & $1 / 10(10.00)$ \\
Microtus arvalis & $0 / 3$ & $1 / 1 /(9.09)$ & $1 / 11(9.09)$ & $2 / 25(8.00)$ \\
Myodes glareolus & $3 / 103(2.91)$ & $3 / 13(23.08)$ & $2 / 62(3.23)$ & $8 / 178(4.49)$ \\
Crocidurina spec. & $0 / 1$ & $-/-$ & $0 / 1$ & $0 / 2$ \\
Sorex spec. & $0 / 3$ & $-/-$ & $-/-$ & $0 / 3$ \\
Not specified & $-/-$ & $-/-$ & $0 / 4$ & $0 / 4$ \\
Total & $4 / 196(2.04)$ & $5 / 46(10.87)$ & $10 / 144(6.94)$ & $19 / 386(4.92)$
\end{tabular}

*-/-, no animals captured

The distribution of $F$. tularensis detection in different small mammal species in the three study sites in absolute and relative numbers is shown. An animal was considered positive for $F$. tularensis when two independent PCR assays demonstrated $F$. tularensis-specific DNA and/or when cultivation of $F$. tularensis was successful.

rodents. However trapping indices in the investigations were good (e. g. in the DA investigation 65 animals/day using 200 traps) suggesting that a rather low prevalence may compensate the high lethality. The overall carrier rate of $4.92 \%$ is strikingly similar to the $4.76 \%$ found among different rodent species in a recently published study from endemic areas in China [15]. Although the route of transmission to hares or humans still remains unclear, $F$. tularensis seems to have a broad host range within small mammals. Because of the complete lack of seroprevalence found, none of them seem to represent a reservoir host for F. tularensis. No tick or flea pool tested positive for the presence of $F$. tularensis either. These findings are supported by the negative testing for $F$. tularensis of more than 2,000 ticks (own unpublished data) over the last years from several areas of Germany, suggesting that neither ticks nor fleas seem to ingest $F$. tularensis and thus are unlikely to be involved in its maintenance and transmission in Germany. These results are in strong contrast to other European countries like Slovakia or the Czech Republic where carrier rates of more than $10 \%$ were reported in ticks, mainly Dermacentor reticulatus, in some endemic areas [16]. This may be due to the fact that Ixodes ricinus is the predominant tick in Germany and reports of Dermacentor reticulatus are sparse (only 2126 between September 2004 and May 2006 in a nationwide study [17]). Water on the other hand seems to be a possible route of infection, since we were able to find $F$. tularensis DNA in a water sample for the first time in Germany. This is paralleled by studies from Scandinavia where water was found to be the source of $F$. tularensis infections [18].

\section{Conclusion}

From 2005 to 2008 tularemia in hares (Lepus europaeus) was reported from 5 out of 16 German federal states. With 20 human tularemia cases in 2007 the highest number in Germany for almost 50 years was notified [7]. This significant change in the incidence of tularemia within the past four years underlines the need for long-term surveillance of natural foci in order to get a better understanding of the reasons for the temporal and spatial patterns of tularemia in Germany.

\section{Competing interests}

The authors declare that they have no competing interests.

\section{Authors' contributions}

PK planned and carried out the investigation in DA, performed the data analysis of all three areas and drafted the manuscript. ES planned and conducted the investigation in GÖ and took part in laboratory testing/data analysis. KMR assisted in planning and took part in the GÖ investigation. MP assisted in planning and took part in the GÖ investigation and laboratory testing. SE took part in the SEN investigation and laboratory testing. WDS coordinated all three investigations (including laboratory testing), planned and conducted the SEN investigation and took part in the DA investigation. All authors contributed to the study design, the preparation of the manuscript and also read and approved the final manuscript.

\section{Acknowledgements}

We thank Kerstin Weiß, Kathleen Hanjohr, Nadine Knauer, Frank Feist, Aileene Lorber and Rudolf Kühn for the excellent cooperation during planning and conduction of these investigations. 
We are grateful to Herbert Helm and the authorities of the county of Darmstadt-Dieburg for their support in planning the DA investigation and Uwe Schönmann for the GÖ investigation.

We would also like to thank Andreas Knoche, Christoph Kleinemeier, Henri Derschum, Brigitte Gramsamer, Heike Prabel, Anne Grumbach, Rahime Terzioglu, Peter Klein, Astrid Thomas, Gudrun Zöller and Gerhard Dobler for excellent technical assistance in preparation and analysis of the samples.

\section{References}

I. Ellis J, Oyston PC, Green M, Titball RW: Tularemia. Clin Microbiol Rev 2002, I 5:631-646.

2. Kneidel H: Die Tularämie in Deutschland. Zentralbl Arbeitsmed 1963, 13:214-218.

3. Splettstoesser WD, Matz-Rensing K, Seibold E, Tomaso H, AI Dahouk S, Grunow R, Essbauer S, Buckendahl A, Finke EJ, Neubauer H: Reemergence of Francisella tularensis in Germany: fatal tularaemia in a colony of semi-free-living marmosets (Callithrix jacchus). Epidemiol Infect 2007, I 35(8): I 256-I 265.

4. Muller W, Bocklisch H, Schuler G, Hotzel H, Neubauer H, Otto P: Detection of Francisella tularensis subsp. holarctica in a European brown hare (Lepus europaeus) in Thuringia, Germany. Vet Microbiol 2007, I 23:225-229.

5. Matz-Rensing K, Floto A, Schrod A, Becker T, Finke EJ, Seibold E, Splettstoesser WD, Kaup FJ: Epizootic of tularemia in an outdoor housed group of cynomolgus monkeys (Macaca fascicularis). Vet Pathol 2007, 44:327-334.

6. Hofstetter I, Eckert J, Splettstoesser W, Hauri AM: Tularaemia outbreak in hare hunters in the Darmstadt-Dieburg district, Germany. Euro Surveill 2006, I I:E0601 I9.

7. SurvStat@RKI [http://www3.rki.de/SurvStat/]

8. Essbauer S, Schmidt J, Conraths FJ, Friedrich R, Koch J, Hautmann W, Pfeffer M, Wolfel R, Finke J, Dobler G, et al.: A new Puumala hantavirus subtype in rodents associated with an outbreak of Nephropathia epidemica in South-East Germany in 2004. Epidemiol Infect 2006, I 34: I333-1344

9. Fujita O, Tatsumi M, Tanabayashi K, Yamada A: Development of a Real-Time PCR Assay for Detection and Quantificaition of Francisella tularensis. Jpn J Infect Dis 2006, 59:46-5I.

10. Johansson A, Farlow J, Larsson P, Dukerich M, Chambers E, Bystrom M, Fox J, Chu M, Forsman M, Sjostedt A, et al:: Worldwide genetic relationships among Francisella tularensis isolates determined by multiple-locus variable-number tandem repeat analysis. J Bacteriol 2004, I 86:5808-58I8.

II. Broekhuijsen M, Larsson P, Johansson A, Bystrom M, Eriksson U, Larsson E, Prior RG, Sjostedt A, Titball RW, Forsman M: Genomewide DNA microarray analysis of Francisella tularensis strains demonstrates extensive genetic conservation within the species but identifies regions that are unique to the highly virulent F. tularensis subsp. tularensis. J Clin Microbiol 2003, 4I:2924-293I.

12. Schmitt P, Splettstosser W, Porsch-Ozcurumez M, Finke EJ, Grunow $R$ : A novel screening ELISA and a confirmatory Western blot useful for diagnosis and epidemiological studies of tularemia. Epidemiol Infect 2005, I 33:759-766.

13. Pikula J, Treml F, Beklova M, Holesovska Z, Pikulova J: Ecological conditions of natural foci of tularaemia in the Czech Republic. Eur J Epidemiol 2003, 18:1091-1095.

14. Anonymous: Tularämie - Zum Vorkommen in Deutschland. Epidemiologisches Bulletin 2007, 7:5I-56.

15. Zhang F, Liu W, Chu MC, He J, Duan Q, Wu XM, Zhang PH, Zhao $\mathrm{QM}$, Yang $\mathrm{H}$, Xin $\mathrm{ZT}$, et al.: Francisella tularensis in rodents, China. Emerg Infect Dis 2006, I 2:994-996.

16. Gurycova D, Vyrostekova V, Khanakah G, Kocianova E, Stanek G: Importance of surveillance of tularemia natural foci in the known endemic area of Central Europe, I991-1997. Wien Klin Wochenschr 2001, I 13:433-438.

17. Menn B: Untersuchungen zur Verbreitung und Ökologie von Dermacentor spec. (Ixodidae, Acari) in Deutschland. In PhD Thesis Rheinische Friedrich-Wilhelms-Universität Bonn; 2006.

18. Berdal BP, Mehl R, Haaheim H, Loksa M, Grunow R, Burans J, Morgan $\mathrm{C}$, Meyer $\mathrm{H}$ : Field detection of Francisella tularensis. Scand J Infect Dis 2000, 32:287-29I.

\section{Pre-publication history}

The pre-publication history for this paper can be accessed here:

http://www.biomedcentral.com/1471-2334/8/157/pre pub
Publish with Biomed Central and every scientist can read your work free of charge

"BioMed Central will be the most significant development for disseminating the results of biomedical research in our lifetime. "

Sir Paul Nurse, Cancer Research UK

Your research papers will be:

- available free of charge to the entire biomedical community

- peer reviewed and published immediately upon acceptance

- cited in PubMed and archived on PubMed Central

- yours - you keep the copyright
BioMedcentral 